Ferdinand, Siarl. "Kiss, Tamás, Székely, István Gergő, Toró, Tibor, Bárdi, Nándor and Horváth, István, eds. 2018. Unequal Accommodation of Minority Rights - Hungarians in Transylvania. New York and London: Palgrave Macmillan. 545 pp., illus." Hungarian Cultural Studies. e-Journal of the American Hungarian Educators Association, Volume 12 (2019) DOI: 10.5195/ahea.2019.368

\title{
Kiss, Tamás, Székely, István Gergő, Toró, Tibor, Bárdi, Nándor and Horváth, István, eds. 2018. Unequal Accommodation of Minority Rights - Hungarians in Transylvania. New York and London: Palgrave Macmillan. 545 pp., illus
}

\author{
Reviewed by Siarl Ferdinand ${ }^{1}$, University of Wales Trinity Saint David
}

Unequal Accommodation of Minority Rights - Hungarians in Transylvania is a volume designed to offer a multidisciplinary perspective on the situation of the autochthonous Hungarians living in Romania. In addition, it offers a meticulous analysis of how this community has been and is still affected by a number of social and political processes implemented after the 1989 regime change in the entire Soviet Bloc. This approach allows the reader to learn about the degree of integration of the Hungarians of Transylvania into Romanian society and about the foreseeable future of this large minority. The theoretical postulations expressed in this book are backed up by findings from a broad range of empirical investigations. These findings and other data are illustrated in maps, graphs and tables that help the reader visualize some situations which, otherwise, may be difficult to understand. Four of the volume editors are based in Romanian institutions and one in Hungary. Tamás Kiss, István Gergö Székely and István Horváth are researchers at the Romanian Institute for Research on National Minorities, Tibor Toró works for the Sapientia Hungarian University of Transylvania, and Nándor Bárdi is a researcher at the Hungarian Academy of Sciences in Budapest. In addition, the volume counts with the collaboration of some other specialists in different fields, such as in religious identity and economy.

According to the editors, Romania's political system and minority-rights scheme have provoked and perpetuated a strong asymmetry between the Romanian majority and the country's minorities. This lack of balance in the ethnic institutional structures of Romania undermines the reproductive capacity of the Hungarian community and strengthens its social marginalization. For this reason, it is important to help the Hungarian minority to find a way to maintain its ethnic boundaries while also preventing its further marginalization. This thesis is constructed on some premises, extracted mostly from historical institutionalism and social constructivism. One of these premises is the existence of two dimensions of the minority, namely political claim-making and community organization. The present volume focuses on five interlinked topics: 1) the Romanian regime's minority policies; 2) the political agency exercised by Transylvanian Hungarian elites; 3) the meso-level institutional structures sustaining ethnic parallelism; 4) the

${ }^{1}$ yeth_kernewek@yahoo.co.uk

$($ (c) $)$ EY

ULIS D-Serke
New articles in this journal are licensed under a Creative Commons Attribution 4.0 International License.

This journal is published by the University Library System of the University of Pittsburgh as part of its D-Scribe Digital Publishing Program and is cosponsored by the University of Pittsburgh Press 
Ferdinand, Siarl. "Kiss, Tamás, Székely, István Gergő, Toró, Tibor, Bárdi, Nándor and Horváth, István, eds. 2018. Unequal Accommodation of Minority Rights - Hungarians in Transylvania. New York and London: Palgrave Macmillan. 545 pp., illus." Hungarian Cultural Studies. e-Journal of the American Hungarian Educators Association, Volume 12 (2019) DOI: 10.5195/ahea.2019.368

social and demographic consequences of the institutional and discursive order of ethnic relations in Romania; and 5) the strategies of boundary reinforcement employed by the Hungarian elites (2-3).

The book at hand is structured in twelve chapters that are divided into three parts. The first part provides an extensive analysis from two different and often opposed perspectives, namely Romania's minority policy and the Hungarian minority's ethnic claim-making strategies. The second part contrasts the political programs and the social reality in different social domains, such as education, religion, media and economy. The volume's third and final part illustrates some findings and other empirical evidence based on research and data extracted from censuses and other documents to support the contentions made in the second part. In each part the first chapter serves as introduction to the other chapters in that part.

In the second chapter, Nándor Bárdi and T. Kiss provide a detailed historical introductory survey of the changing perceptions of the Hungarian minority by the (Romanian) central power since 1919. The authors argue that the minority community "must not be viewed as a passive subject but rather as a group looking for adaptation to the socio-political changes" in Romania (38). This long chapter sets the historical basis for the analysis of the political claim-making of the Transylvanian Hungarians carried out by T. Kiss, Toró and Székely in the third chapter. The three propose that this aspect of the Hungarian minority acquired a broader perspective only after the establishment of the Democratic Alliance of Hungarians in Romania (RMDSZ), in 1990, as a sociopolitical movement strongly based on the informality of relations between the county's majority and minority. The three authors, however, show that the strategies followed by RMDSZ and some NGOs have resulted in limited success. The last chapter in this part, the fourth in the book, by Horváth and Toró, discusses what they call "the most important characteristics" of the Hungarian community, namely their linguistic behavior and attitudes and, by extension, the language policies that shape language uses in the area (167). After unveiling that most Hungarians are compelled to employ Romanian in their public lives in contrast to an almost total dominance of Hungarian in their private domains, the researchers link this phenomenon to the language ideologies of the Romanian and Hungarian communities of Transylvania.

In the introductory chapter of the second part, T. Kiss and Dénes Kiss discuss how the idea of parallel society or ethnic parallelism can be partly applied to the situation of the Hungarian minority in Romania due to the existence of several social fields organized in ethnically separated structures. This chapter, the fifth in the volume, opens the way to a discussion of some systems in which Hungarians and Romanians are organized in parallel structures, namely education, religious life, media and society. In Chapter Six, Attila Z. Papp, János Márton, I.G. Székely, and Gergő Barna argue that although the Romanian system allows the development of education in vernacular languages at all levels, the state's centralization and its ownership of the schools in fact work against this development. Besides the implementation of a specific structure to develop the Hungarian education system to its maximum potential, the authors propose compilation and analysis of accurate data about the system itself.

An important gap between the Romanian and the Hungarian communities is directly linked to their religious adscription. While Romanians are almost unanimously Orthodox, Hungarians are symmetrically divided between Roman Catholicism and a number of Protestant churches. In Chapter Seven, D. Kiss states that the Hungarian churches have become some of the most powerful parallel organizations due to their influence among a high percentage of 
Ferdinand, Siarl. "Kiss, Tamás, Székely, István Gergő, Toró, Tibor, Bárdi, Nándor and Horváth, István, eds. 2018. Unequal Accommodation of Minority Rights - Hungarians in Transylvania. New York and London: Palgrave Macmillan. 545 pp., illus." Hungarian Cultural Studies. e-Journal of the American Hungarian Educators Association, Volume 12 (2019) DOI: 10.5195/ahea.2019.368

Hungarian Transylvanians and the important amount of resources they manage and control. The media is also a strong pivot to articulate the Hungarian society of Transylvania. However, T. Kiss provides, in Chapter Eight, evidence of the weakness of this domain, since the strong dominance of the Hungarian language only works on the regional level while the national one has been covered by the Hungarian (here meaning from Hungary) transnational media. Finally, In Chapter Nine, Zsombor Csata argues that the role of ethnicity in shaping economic processes not only has an important weight in Transylvania but it also is increasing, mostly due to the territorial concentration of the Hungarian population.

All the three chapters of the third part are by T. Kiss. In the first of them, Chapter Ten, the author offers a wide perspective about the demography of the Hungarian population in Romania backing it up with a strong historical base. In addition to the already mentioned Magyars and Szeklers, in Chapter Eleven Kiss briefly reviews the situation of Csángós and Hungarian Roma. After assessing the historical population-rates of Hungarians and other groups of Transylvania, he concludes that currently there is a phenomenon of increasing marginalization of the Transylvanian Hungarians. One of the reasons for this is the privileged position of the ethnic Romanians within a state in which they are the titular nationality. Finally, in Chapter Twelve, Kiss offers an analysis of the dichotomy between assimilation and ethnic-boundary reinforcement.

Unequal Accommodation of Minority Rights - Hungarians in Transylvania is a key work in that it presents an accurate and updated view of the social situation of Transylvania. Despite the work's profound roots in historical institutionalism and social constructivism, the reading is easy even for those with different backgrounds due to the clear explanations that it offers. Moreover, the large number of subsections in each chapter and the many graphs and tables illustrating the findings are an invaluable help. The volume is presented from the Hungarian perspective, however in no case does it fall into Hungarian chauvinism or any antiRomanian rhetoric. Yet, it would have been advisable to include a full chapter as opposed to a brief survey (within Chapter 11) about the situation of other Hungarian groups such as Csángós and Hungarian-speaking Roma. In all other respects the team of researchers behind this collection deserve the highest commendation for having produced a volume that thoroughly explores such a complex issue as the interethnic relations of groups with a long history of enmity. All the more so since they carried out their research in a dangerous period in which nationalism seems to be advancing rapidly all over the world as well as in the region they study and live in. 